Marković, M., Radonjić, D., Đokić, M., Kandić, A., Marković, B. (2021): Allelic polymorphism of k-casein gene (csn3) in three Montenegrin cattle breeds. Agriculture and Forestry, 67 (3): 61-70

DOI: 10.17707/AgricultForest.67.3.05

\begin{abstract}
Milan MARKOVIĆl, Dušica RADONJIĆl, Milena ĐOKIĆ , Aleksandra KANDIĆ , Božidarka MARKOVIĆ
\end{abstract}

\title{
ALLELIC POLYMORPHISM OF K-CASEIN GENE (CSN3) IN THREE MONTENEGRIN CATTLE BREEDS
}

\section{SUMMARY}

Genetic polymorphism of $\kappa$-casein gene was investigated in three cattle breeds reared in Montenegro: Brown Swiss, Busha and Gray breeds of cattle. The DNA of these breeds was genotyped for polymorphisms at the kappa-casein gene by a Polymerase Chain Reaction-Restriction Fragment Length Polymorphism (PCR-RFLP) essay. A $351 \mathrm{bp}$ fragment of $\kappa$-casein was amplified and digested with HinfI restriction endonuclease. Three genotypes were identified (AA, AB and $\mathrm{BB}$ ) with frequencies of $0.162,0.501$ and 0.356 (respectively) in Brown Swiss breed, 0.267, 0.501 and 0.233 in Busha breed and 0.236, 0.500 and 0.264 in Gray cattle breed. The frequencies of alleles A and B were 0.403 and 0.597 (respectively) in Brown Swiss, 0.517 and 0.483 in Busha cattle and 0.486 and 0.514 in Gray cattle. The genotyping of $\kappa$-casein alleles (A and B) is of practical importance, since B allele is in positive correlations with commercially valuable parameters of cheese yielding efficiency. The results of high frequency of B allele in Brown Swiss cattle confirmed a good performance of this breed in Montenegrin population. Results could be used for possible increasing the frequency of desired alleles and genotypes by including it in the breeding program for Brown Swiss breed as well as in the preservation program for Gray cattle and Busha as the important animal genetic resources in Montenegro.

Keywords: $\kappa$-casein, PCR-RFLP, Busha, Brown Swiss, Gray cattle

\section{INTRODUCTION}

Molecular biology and genomic selection techniques development have enabled to obtain more detailed information on the individual genome structure. The discovery of PCR-RFLP (Polimerase Chain Reaction - Restriction Fragment Lenght Polymorphism) generated renewed interest in the use of gene marker loci as an aid to selection programs and playing an increasingly important role as genetic markers in many fields of animal breeding. By the PCR-RFLP technique it is possible to determine the variability of milk protein fractions.

\footnotetext{
${ }^{1}$ Milan Marković, Dušica Radonjić, Milena Đokić (corresponding author: milena.dj1405@gmail.com), Aleksandra Kandić, Božidarka Marković, University of Montenegro, Biotechnical Faculty, Mihaila Lalića 15, Podgorica, MONTENEGRO

Notes: The authors declare that they have no conflicts of interest. Authorship Form signed online.

Recieved:14/07/2021

Accepted:21/09/2021
} 
Cow milk contains two classes of specific proteins, i.e., the group of caseins and the group of whey proteins. Caseins constitute about $78-82 \%$ of bovine milk proteins and subdivided into four main groups: $\alpha \mathrm{S} 1$-casein, $\alpha \mathrm{S} 2-$ casein, $\beta$-casein, and $\kappa$-casein (Azevedo et al., 2008, Smiltina and Grīslis, 2010, Hristov et al., 2012).

Genetic variants of $\kappa$-casein have been extensively studied in cattle at the protein and DNA levels, and numerous alleles have been revealed (Tanaskovska et al., 2016). K-casein ( $\kappa-\mathrm{CN})$ is being determined by the gene positioned at the $6^{\text {th }}$ bovine chromosome. The genomic DNA encoding the CSN3 milk protein is about $13 \mathrm{~kb}$ that is divided into 5 exons and intervening sequences (Azevedo et al., 2008, Smiltina and Grīslis, 2010). Some authors reported fourteen polymorphic types of $\kappa-\mathrm{CN}$ (A, A1, B, B2, C, D, E, F1, F2, G1, G2, H, I, J). The $\mathrm{A}$ and the $\mathrm{B}$ alleles are the most frequent among all the species of the genus Bos (Djedović et al., 2015, Dokso et al., 2014, Hristov et al., 2012). The existence of the $\mathrm{E}$ allele in some dairy cattle breeds was reported in the papers of Soria et al. (2003), Caroli et al. (2010), Taha and Punan (1993).

The genetic variants of milk proteins are resulting as a consequence of substitution or deletion of amino acids within the polypeptide chain (El Rafey and Darwish, 2008). A and B variants of $\kappa$-casein differ in the amino acids 136 and 148. At position 136, threonine is replaced by isoleucine, while at position 148 , aspartic acid is replaced by alanine, for A and B, respectively (Azevedo et al., 2008, Deb et al., 2014, Dogru and Ozdemir, 2009). The restriction endonucleases HindIII, HaeIII, and MaeII could be used for distinguishing $\kappa$-casein alleles (Soria et al., 2003).

One of the most important effects of the milk protein polymorphisms on milk traits of economic importance is their relation to the technological properties of milk and cheese production. In most of the $\kappa$-casein studies, the association of the $\mathrm{B}$ allele variant with some quantitative and milk processing traits was identified. The B allele found to be associated with thermal resistance, shorter coagulation time, better curdles and micelles of different sizes, which are preferable in cheese making (Azevedo et al, 2008, Dokso et al., 2014). In majority of recent studies, a positive effect of $\kappa-\mathrm{CN}-\mathrm{B}$ allelic variant on the share of casein and total milk proteins has been observed (Molina et al., 2006, Djedović et al., 2015). The cheese yield from cows with genotype BB is $10 \%$ higher than in cows with AA genotype (Deb et al., 2014, Tanaskovska et al., 2016).

Identification of the polymorphic gene variants of milk proteins associated with productive traits opens additional possibilities for improvement of production of different breeds (Djedović et al., 2015). B allele of $\kappa$-casein gene is integrated into cattle breeding programs in many countries. In recent years, some countries started trading milk and dairy products with desirable kappa and/or beta casein as well as breeding animals with genotype for kappa and/or beta casein. In some countries the genotype for $\kappa$-casein is present in sire catalogues for a long time (Potočnik, 2015). 
Cattle husbandry in Montenegro is the most important branch of animal husbandry and agriculture in general. Annual production of cow's milk is about 180 thousand tons. Breed composition of Montenegrin cattle population is quite unfavorable because various crossbreeds dominate, about $50 \%$ of the total population. In the last two decades share of high productive breeds Holstein and Simmental has been increased, at the same timeBrown Swiss and Grey cattle sharply decreased, while autochthonous Busa breed is in risk of extinction.

The aim of this study was to identify the genetic variants of $\kappa$-casein in three cattle breeds reared in Montenegro for a longer period (Busha, Grey cattle and Brown Swiss) by use the PCR-RFLP technique. The studies of milk protein genes polymorphism and their application for the identification of individuals with desirable characteristics as well as for the selection and breeding programs is the future. Genotyping is very important for the evaluation of biodiversity and preservation of these cow breeds.

\section{Animals}

\section{MATERIAL AND METHODS}

Blood samples were obtained from 96 cows of three breeds: 30 samples were collected from Busha cattle 31 samples from Brown Swiss and 35 samples were collected from Gray cattle.

Busha is an autochthonous breed of cattle, which was the most dominant breed in Montenegrin cattle population till the seventies of XX century, (approximately 90\%). In the second half of XX century, Busha breed had been crossed or just replaced by more productive breeds. Today, Busha is endangered breed, with less than 300 animals and because of that it is involved in the program of in situ conservation (Marković et al., 2020).

The Gray cattle in Montenegro today is a local breed originated from Tyrolean grey breed. First time it was imported on beginning of XX century as well as after Second World War, till the sixties, and used for improvement of production traits of Busha cattle. This breed is very adaptable, resistant and very suitable for hilly mountain region of Montenegro. However, its population is permanently decreased and now its share in total cattle population is about $5 \%$ (Marković et al., 2020).

Brown cattle in Montenegro originated from Brown Swiss breed, which is occasionally imported since the seventies of last century (Radonjić et al., 2017). The population of the Brown breed in Montenegro participates by $12 \%$ in the total cattle population (Marković et al., 2020).

\section{DNA extraction from blood}

Blood samples were collected from v. jugularis into vacuum tube K2EDTA $(3 \mathrm{ml})$. The blood samples were maintained at $-20^{\circ} \mathrm{C}$ until used for DNA extraction. DNA extraction was performed using DNA isolation kit (ZYMO research, USA) according to manufacturer's instructions, while phenolchloroform standard protocol used for some samples (Marković et al., 2018). The quality of DNA was checked by Nano-Vue Spectrophotometer taking ratio of 
optical density (OD) value at 260 and $280 \mathrm{~nm}$. Also, the quality of the DNA samples was examined on $1 \%$ agarose gel.

\section{Genotyping of kappa-casein gene by PCR-RFLP method}

The $\kappa$-casein genotype was determined using PCR-RFLP. Amplification of 351 $b p$ fragment of $\kappa$-casein was done using the polymerase chain reaction (PCR) with primers: forward (5'-TT TAT GGC CAT TCC ACC AA-3') and reverse (5'ATT AGC CCA TTT CGC CTT CT-3') as reported by Dogru and Ozdemir (2009). The amplification was performed in $30 \mu 1$ of final volume with $100 \mathrm{ng}$ of genomic DNA. The reaction mix contained 10xPCR buffer, $\mathrm{MgCl} 2(1.5 \mathrm{mM})$, dNTP nucleotides $(100 \mu \mathrm{M}), 1 \mu \mathrm{M}$ of each primers and AmpliTaq Gold polymerase $(0.5 \mathrm{U})$. Amplification was performed in Mastercycler Pro (Eppendorf) gradient programmed for initial denaturation at $94^{\circ} \mathrm{C}$ for $5 \mathrm{~min}$ (initial denaturation), followed by 30 cycles of denaturation at $94^{\circ} \mathrm{C}$ for $45 \mathrm{sec}$, annealing at $60^{\circ} \mathrm{C}$ for $45 \mathrm{sec}$, extension at $72^{\circ} \mathrm{C}$ for $60 \mathrm{sec}$, and final extension at $72^{\circ} \mathrm{C}$ for $7 \mathrm{~min}$. PCR products were checked for amplification by electrophoresis on $1 \%$ agarose gel, in parallel with 50 and 100 bp DNA marker (Đokić et al., 2020).

For genotyping, PCR product was digested with Hinf I restriction enzyme which was used for the determination of $\kappa$-casein alleles. The total reaction mixture of $15 \mu \mathrm{L}$ comprised of $10 \mu \mathrm{L}$ of PCR product, $1.5 \mu \mathrm{L}$ of enzyme buffer, $5 \mathrm{U}$ of restriction enzyme and $3.2 \mu \mathrm{L}$ of $\mathrm{dH}_{2} \mathrm{O}$. After digestion at $37^{\circ} \mathrm{C}$ for three hours the digested products were resolved by electrophoresis on $3 \%$ agarose gel in parallel with a $100 \mathrm{bp}$ DNA marker. The genotype patterns were visualized under UV light by Quantum ST400. The genotypes of cattle $\kappa$-casein gene were identified on the base of restricted fragments size.

\section{Statistical analysis}

Allele and genotype frequencies for the genetic variants of $\kappa$-casein gene were analyzed by Hardy-Weinberg equilibrium calculator including analysis for ascertainment bias (Rodriguez et al., 2009). The chi-square statistic used to check whether the populations were in Hardy-Weinberg equilibrium: http://www.husdyr.kvl.dk/htm/kc/popgen/genetik/applets/kitest.htm.

\section{RESULTS AND DISCUSSION}

Frequencies of genotypes and allele of $\kappa$-casein (CSN3) were detected in 96 individuals, in Brown Swiss, Busha and Gray cattle. PCR amplification of the 351-bp fragment of the $\kappa$-casein gene produced a clear and distinct band on the gel, which is of major importance for successful digestion step of PCR products (Figure 1). Digestion of the PCR products with endonuclease HinfI generated presence of three fragments (Table 1).

The genotype $\mathrm{AB}$ had highest frequencies of all genotypes in the investigated breeds: 0.501 in Brown Swiss and Busha and 0.500 in Gray cattle. The frequency of BB genotype was higher in Brown Swiss than in Busha breed and Gray cattle (0.356 and $0.233,0.264$, respectively). 
According to $\chi 2$ test, all breeds were in Hardy-Weinberg equilibrium, suggesting that the $\kappa$-casein gene in investigated population was not influenced by selection (Table 2). Higher share of observed $\mathrm{AB}$ and $\mathrm{BB}$ genotypes determined in Brown Swiss breed could be a consequence of use of homozygous bulls (semen) to "desirable" allelic polymorphic B form. The frequency of AA genotype of Brown Swiss breed was the lower (0.162), than for Busha and Gray cattle (0.267 and 0.236).

Many other authors (Taha and Punan, 1993, Dogru and Ozdemir, 2009, Dokso et al., 2014, Djedović et al., 2015) found that the frequency of the AB genotype in the Brown Swiss breed was higher compared to other genotypes, while Potočnik (2015) determined a higher share of BB genotypes compared to $\mathrm{AA}$ and $\mathrm{AB}$ in this breed. The higher frequency of BB genotype in Jersey cattle (0.772) with absent of opposite AA genotype is reported by Ren et al., 2011.

Table 1. Expected /observed fragment sizes (in base pairs, bp) after restriction PCR products with HinfI

\begin{tabular}{|c|ccc|}
\hline \multirow{2}{*}{ PCR Product (bp) } & \multicolumn{3}{|c|}{ Restriction Fragments Sizes (bp) and determined genotypes } \\
\cline { 2 - 4 } & AA & AB & BB \\
\hline 351 & $131 ; 89$ & $261 ; 131 ; 89$ & $261 ; 89$ \\
\hline
\end{tabular}

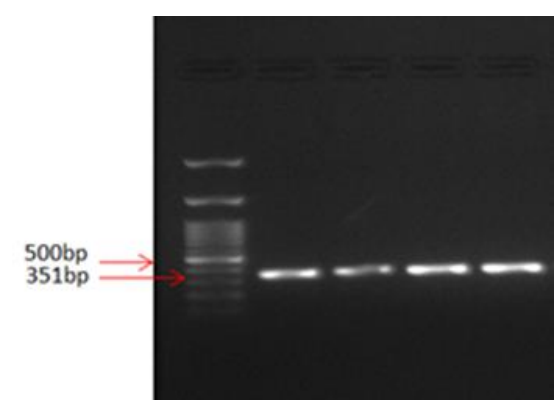

Figure 1. PCR products of $\kappa$-casein gene polymorphism visuelised on $1 \%$ agarose gel

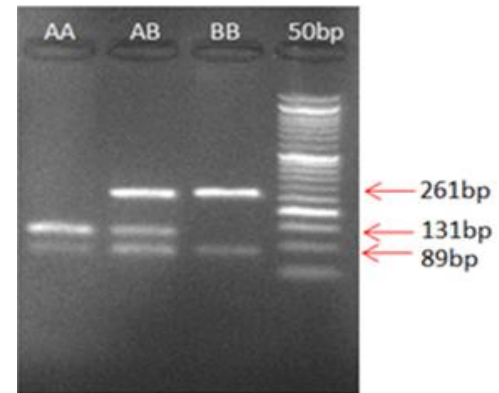

Figure 2. PCR-RFLP of $\kappa$-casein gene using Hinf I on 3\% agarose gel 
Table 2. Frequencies of genotypes and alleles and Hardy Weinberg equilibrium test for $\mathrm{K}$-casein locus of Brown Swiss, Busha and Gray cattle breeds

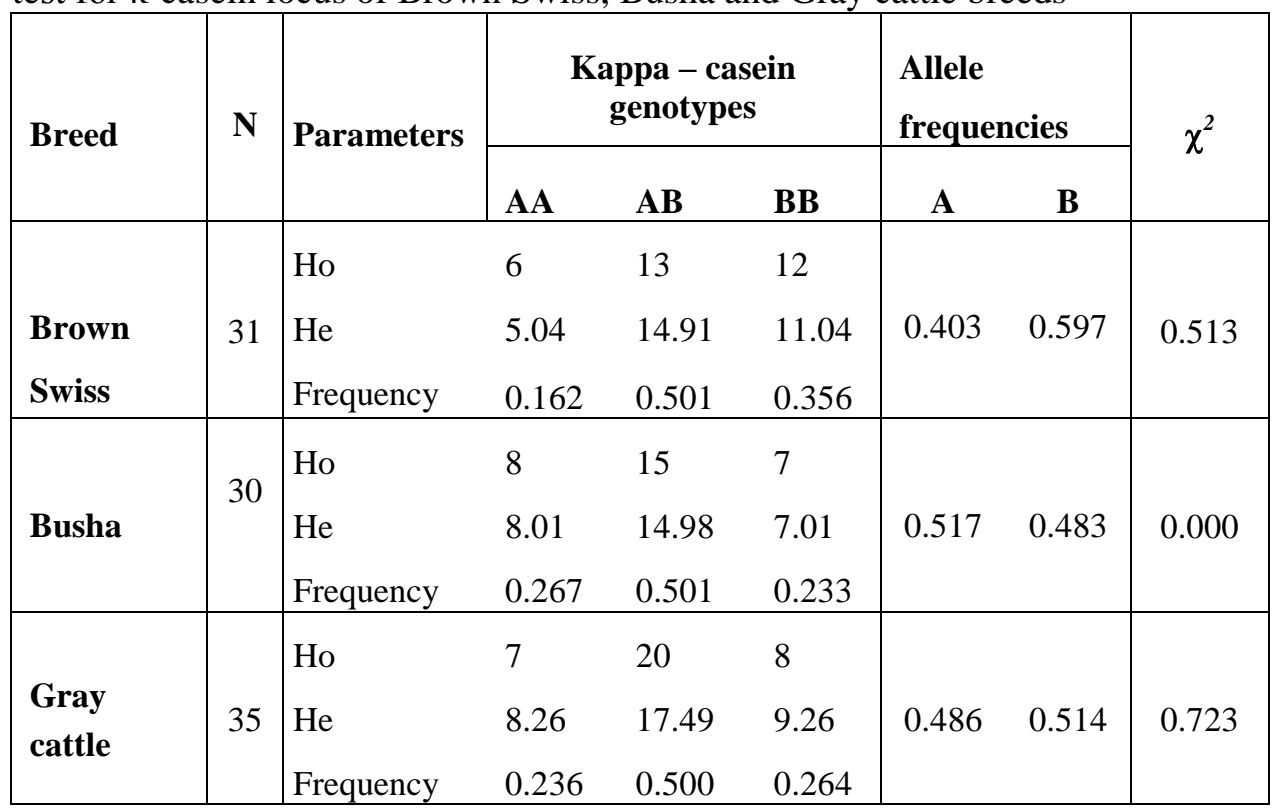

Ho: observed heterozygotes, He: expected heterozygotes on the basis of HardyWeinberg, $\chi 2=$ chi-square value

Similar to our research, Djedović et al. (2015), Maletić et al. (2016), Brka et al. (2010) also obtained that heterozygote genotype of $\kappa$-casein (AB) was dominant in Busha breed. Only in the research of Ivanković et al. (2011) determined dominance of BB homozygote. Brka et al. (2010) found BC genotype at a low frequency (0.143), which was not found in Busha cattle in Montenegro.

For high productive Holstein Friesian breed some authors (Volkandari et al., 2017, Tanaskovska et al., 2016, Khaizaran and Razem, 2014, Dokso et al., 2014, Ren et al., 2011) determined higher frequency of AA genotype than AB and BB genotypes, what is similar to result obtained for Brown Swiss breed. Other authors, as Doosti et al. (2011), Gouda et al. (2013), Maletić et al. (2016) reported for Holstein breed the highest frequency of $\mathrm{AB}$ genotype $\kappa$-casein.

Different to our results, Djedović et al. (2015), Ivanković et al. (2011), Dokso et al. (2014), Taha and Punan (1993) identified very low frequency of BB homozygous of $\kappa$-casein gene for Simmental breed, predominantly lower compared to $\mathrm{AA}$ and $\mathrm{AB}$ genotypes. The frequency of $\mathrm{BB}$ genotype in the Simmental breed ranged from 0.096 (Djedović et al., 2015) to 0.220 (Taha and Punan, 1993).

On the other side, the results of genotyping k-caseine of Czech Fleckvieh, Bulgarian Rhodopean Cattle, Shorthorn Rhodopean Cattle as old autchthonous breed (Kučerová et al., 2006 and Hristov et al., 2012), as well as results for Gatačko cattle reared in Bosnia and Herzegovina (Brka et al., 2010) show strong 
domination of the $\mathrm{AB}$ genotype, as it obtained for Gray cattle breed in Montenegro.

Table 3. The frequency of genotypes $\kappa$-casein in some cattle breeds reported by other authors)

\begin{tabular}{|c|c|c|c|c|}
\hline \multirow{2}{*}{ Breed } & \multicolumn{3}{|c|}{ Frequency of k-casein genotypes } & \multirow{2}{*}{ Source } \\
\hline & $\mathbf{A A}$ & $\mathbf{A B}$ & BB & \\
\hline $\begin{array}{c}\text { Brown Swis } \\
\text { (Slovenia) }\end{array}$ & 0.069 & 0.387 & 0.544 & Potočnik, 2015 \\
\hline Swiss Brown & 0.279 & $\begin{array}{c}0.480 \\
\text { AC } 0.039\end{array}$ & $\begin{array}{c}0.167 . \\
\text { BC } 0.034\end{array}$ & Taha et al., 1993 \\
\hline $\begin{array}{c}\text { Crosses Brown } \\
\text { cattle } x \\
\text { American Brown } \\
\text { Swiss } \\
\end{array}$ & 0.168 & $\begin{array}{c}0.466 . \\
\text { AC } 0.016\end{array}$ & $\begin{array}{c}0.334 . \\
\text { BC } 0.016\end{array}$ & Taha et al., 1993 \\
\hline Brown Swiss & 0.194 & 0.602 & 0.204 & Dogru and Ozdemir, 2009 \\
\hline Brown Swiss & 0.392 & 0.449 & 0.159 & Dokso et al., 2014 \\
\hline Busha & 0.417 & 0.500 & 0.083 & Djedović et al., 2015 \\
\hline Busha & 0.444 & 0.555 & 0.00 & Maletić et al., 2016 \\
\hline Busha & 0.206 & 0.294 & 0.500 & Ivanković et al., 2011 \\
\hline Busha & 0.286 & 0.357 & $\begin{array}{c}0.214 . \\
\text { BC } 0.143\end{array}$ & Brka et al., 2010 \\
\hline Gatačko* & 0.308 & 0.538 & 0.154 & Brka et al., 2010 \\
\hline
\end{tabular}

*Gatačko cattle is local name for population of Gray cattle breed reared in South East Bosnia and Herzegovina

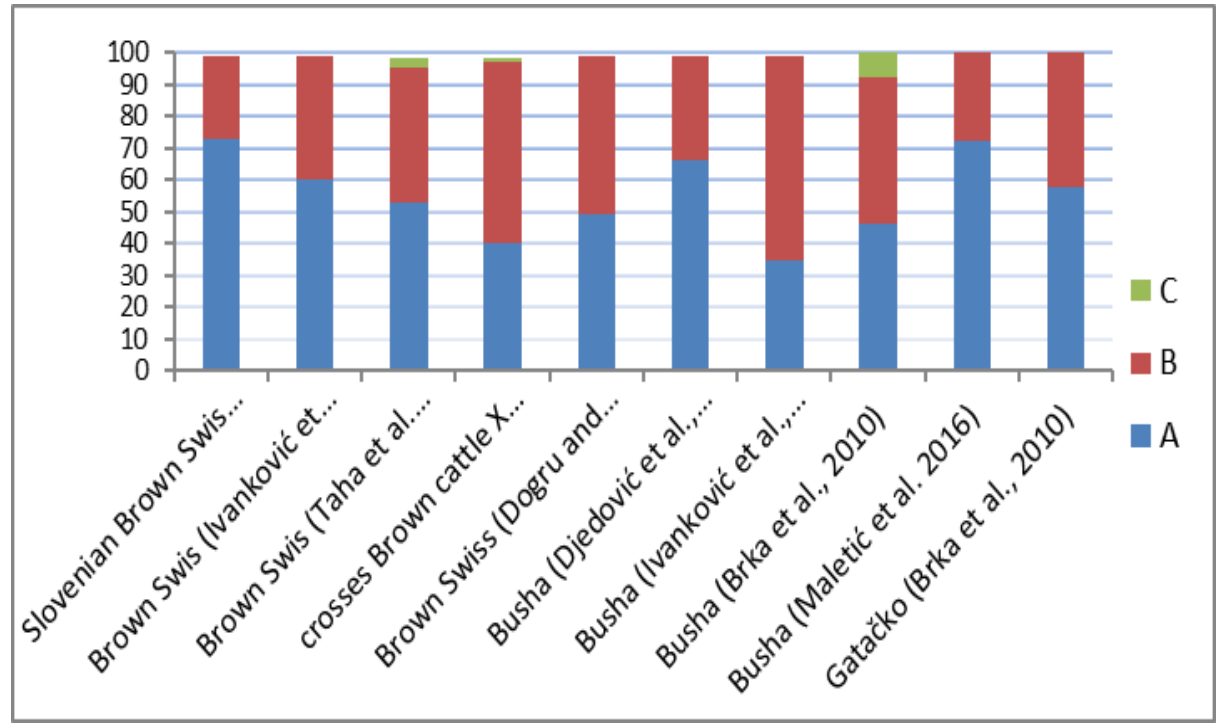

Graph 1. Percentage of allelic CSN3 variants in cattle breeds (different authors) 
In regarding allele frequencies of $\kappa$-casein gene for all three investigated breeds, slightly higher frequencies of A allel than B allele were determined. It was for Busha breed 0.517, Brown Swiss breed 0.597 and for Gray cattle 0.514.

Brka et al. (2010) obtained the similar ratio of A and B allele for Gatačko cattle (A - 0.58, B - 0.42) and Dogru and Ozdemir (2009) for Brown Swiss breed reared in Turkey. Very high frequency of allele A was reported by Potočnik (2015) for population of Brawn Swis in Slovenia (0.737) and Ivanković et al. (2011) for Brown Swiss in Croatia (0.607), Graph 1.

The higher frequency of A allele than allele B of Montenegrin Busha breed in our present study is in agreement with the earlier observations for Busha breed reared in other countries of Western Balkan, as it was reported for Busha in Serbia (Djedović et al. 2015, Maletić et al., 2016) and for Busha reared in Bosnia and Herzegovina (Brka et al., 2010). However, our results are not in accordance with the results for Busha breed in Croatia where lower frequency of A than B allele was found (Ivanković et al., 2011).

Allele B of $\kappa$-casein was a favorable in cattle population because it significantly affected both milk and milk protein yield of Holstein and Native Iranian breed (Doosti et al., 2011). Kučerová et al. (2006) also reported higher frequency of A allele (0.62) than allele B (0.38) in population of Czech Simmental cattle breed. Similar results for allele and genotype frequencies found in Czech Simmental (Fleckvieh) cattle population Kučerová et al. (2006), Holstein Friesian cattle in Macedonia and for some commercial cattle breeds in Croatia (Tanaskovska et al., 2016, Ivanković et al., 2011).

\section{CONCLUSIONS}

The results of PCR-RFLP analysis showed that three genotypes (AA, BB and $\mathrm{AB}$ ) were found in the population studied for $\kappa$-casein gene. The results of very high frequency of $\mathrm{B}$ allele in Brown Swiss cattle implied that this breed should have a good performance in the milk traits related to the B allele of $\kappa$ casein gene. Hence, future studies should be focused on the association between cattle genotype and milk composition characteristics.

Determination of A and B allele frequencies in population of Busha and Grey cattle breeds could be used in the programs of selection and preservation, as important animal genetic resources in Montenegro, in order to increase frequency of desired alleles and genotypes.

Knowledge about genetic profile of breeds due to studied polymorphic variants of milk proteins is useful in further breeding development and economic valorization of cattle breeds, especially autochthonous and local ones.

\section{REFERENCES}

Azevedo, A.L.S., Nascimento, C.S., Steinberg, R.S., Carvalho, M.R.S., Peixoto, M.G.C.D., Teotdoro, R.L., Verneque, R.S., Guimaraes, S.E.F., Machado, M.A. (2008): Genetic polymorphisms of the kappa-casein gene in Brazilian cattle, Genetics and Molecular Research. 7 (3), 623-630. doi: 10.4238/vol7-3gmr428. 
Brka, M., Hodžic, A., Reinsch, N., Zecevic, E., Dokso, A., Djedovic, R., Rukavina, D., Kapur, L., Vegara, M., Šabanovic, M., Ravic, I. (2010): Polymorphism of the kappacasein gene in two Bosnian autochthonous cattle breeds. Arch Tierz. 53: 277-282.

Caroli, A., Rizzi, R., Lühken, G. and Erhardt G. (2010): Milk protein genetic variation and casein haplotype structure in the Original Pinzgauer cattle.J. Dairy Sci. 93 :1260-1265 doi: 10.3168/jds.2009-2521.

Deb, R., Singh, U., Kumar, S., Singh, R., Sengar, G., Sharma, A. (2014): Genetic polymorphism and association of kappa-casein gene with milk production traits among Frieswal $(\mathrm{HF} \times$ Sahiwal) cross breed of Indian origin. Iran $\mathrm{J}$ Vet Res.15(4):406-408.

Djedović, R., Bogdanović, V., Perišić, P., Stanojević, D., Popović, J., Brka, M. (2015): Relationship between genetic polymorphism of $\kappa$ - casein and quantitative milk yield traits in cattle breeds and crossbreds in Serbia. Genetika, Vol 47, No. 1, 23 - 32.

Djokić, M., M., Marković, B., Gantner, V., Marković, M. (2020): Association of genetic variants of $\beta$-lactoglobulin gene with milk traits of Jezeropivska sheep breed. Agriculture and Forestry 66(3):15-23.

Dogru, U. \& Ozdemir, M. (2009): Genotyping of Kappa-Casein Locus by PCR-RFLP in Brown Swiss Cattle Breed. Journal of Animal and Veterinary Advances, 8: 779-781.

Dokso, A., Ivanković, A., Brka, M., Zečević, E., Ivkić, Z. (2014): Utjecaj genetskih varijanti $\beta$-laktoglobulina, $\kappa$-kazeina i as1-kazeina na količinu i kvalitetu mlijeka holstein, simentalske i smeđe pasmine goveda u Hrvatskoj, Mljekarstvo. 64 (1), 4956.

Doosti, A., Arshi, A., Vatankhah, M. and Amjadi, P. (2011): Kappa-casein gene polymorphism in Holstein and Iranian native cattle by polymerase chain reaction restriction fragment length polymorphism (PCR-RFLP). African Journal of Biotechnology Vol. 10(25), pp. 4957-4960.

El Rafey, G. \& Darwish, S.F. (2008): PCR-RFLP assay to detect genetic variants of kappa-casein gene in cattle and buffalo. Arab Journal of Biotechnology; 11 (1): 11 18.

Gouda, E., M., Galal, M.K. \& Abdelaziz, S.A. (2013): Genetic Variants and Allele Frequencies of Kappa Casein in Egyptian Cattle and Buffalo Using PCR-RFLP. Journal of Agricultural Science; Vol. 5, No. 2; ISSN 1916-9752 E-ISSN 1916-9760

Hristov, P., Teofanova, D., Mehandzhiyski, I, Zagorchev, L and Radoslavov, G. (2012): Application of Milk Proteins Genetic Polymorphism for Selection and Breeding of Dairy Cows in Bulgaria. Milk Production - Advanced Genetic Traits, Cellular Mechanism, Animal Management and Health. DOI: 10.5772/50758

Ivanković, A., Ramljak, J., Dokso, A., Kelava, N., Konjačić, M., Paprika, S. (2011): Genetski polimorfizam $\beta$-laktoglobulina i $\kappa$-kazeina pasmina goveda u Hrvatskoj, Mljekarstvo. 61 (4), 301-308.

Khaizaran, Z.A., Al-Razem, F. (2014): Analysis of selected milk traits in Palestinian Holstein-Friesian cattle in relation to genetic polymorphism Article Number 7C7F74544445 Vol.8(5), pp. 74-85, https://doi.org/10.5897/JCAB2014.0409

Kučerová, J., Metějíčková, A., Jandurová, O.M., Sørensen, P., Nemcova, E., Stipková, M., Kott, T., Bouška, J. \& Frelich, J. (2006): Milk protein genes CSN1S1, CSN2, CSN3, LGB and their relation to genetic values of milkproduction parameters in Czech Fleckvieh. Czech J. Anim. Sci., 51: 241-247.

Maletić, M., Aleksić, N., Vejnović, B., Nikšić, D., Kulić, M., Đukić, B., Ćirković, D. (2016): Polymorphism of $\kappa$-casein and $\beta$-lactoglobulin genes in Busha and Holstein Friesian dairy cows in Serbia. Mljekarstvo 66 (3), 198-205 
Marković, B., Marković, M., Adžić, N. (2020): Genetic resources in the livestock of Montenegro. Montenegrin Academy of Sciences and Arts. Monographies and Studies, Volume 157.

Marković, B., Marković, M., Trivunović, S., Mirecki, S., Antunović, Z., Veljić, M. (2018): Effects of the alpha s1-casein genotype on milk yield and milk composition of Balkan goat in Montenegro. Agriculture \& Forestry, Vol. 64 Issue 3: pg. 05-14,

Molina, L.H., Benavides, T., Brito, C., Carrillo, B., Molina, I. (2006): Relationship between $\mathrm{A}$ and $\mathrm{B}$ variants of $\kappa$-casein and $\beta$-lactoglobulin and coagulation properties of milk (Part II.). International Journal of Dairy Technology, 59, 188-191.

Potočnik, K. (2015): Selection adapted to local conditions has the possibility to improve the economy of small dairy cattle populations. International Symposium on Animal Science. 09-11.09. Novi Sad, Serbia. UDK: 547.963.2:576.113

Radonjić D., Marković B., Drobnjak D., Marković M. (2017): Linear scoring of Brown swiss cattle breed in Montenegro, 249-259. AgricultForest.63.1.28

Ren, D.X., Miao, S.Y., Chen, Y.L., Zou, C.X., Liang, X.W. \& Liu, J.X. (2011): Genotyping of the k-casein and $\beta$-lactoglobulin genes in Chinese Holstein, Jersey and water buffalo by PCR-RFLP. J. Genet. 90, e1-e5. Online only: http://www.ias.ac.in/jgenet/ OnlineResources/90/e1. pd.

Rodriguez, S., Gaunt, T.R. \& Day, I.N.M. (2009). Hardy-Weinberg Equilibrium Testing of Biological Ascertainment for Mendelian Randomization Studies. American Journal of Epidemiology Advance Access, DOI 10.1093/aje/kwn359.

Smiltina, D. \& Grīslis, Z. (2010): Analysis of kappa-casein (CSN3) alleles in Latvian Brown and Latvian Blue breed cows' populations. Conference: 16th International Scientific Conference' Research for Rural Devepolment 2010' At: Latvia University of Agriculture, Jelgava, Latvia Volume: 1, p. $71-74$

Soria, L.A., Iglesias, G.M., Huguet, M.J. \& Mirande, S.L. (2003): A PCR- RFLP Test to Detect Allelic Variants of the Bovine Kappa- Casein Gene, Animal Biotechnology, 14:1, 1-5, DOI: 10.1081/ABIO-120020180

Taha,F. \& Punan, Z. (1993): Milk protein polymorphism in Swiss dairy cattle. Agric. Sci. Finl. 2: 423-429. Lab. Dairy Sci., Swiss Federal Inst. Techn., CH-8092 Zurich, Switzerland.

Tanaskovska, B., Srbinovska, S., Andonov, S., Trojacanec, S., Nestoriovski, T., Popovski, Z. (2016): Genotipization of k-Casein in Holstein- Friesian Cattle in Macedonia and its Association With Some Milk Properties. International Journal of Agriculture Innovations and Research. 5: (2).

Volkandari, S.D., Indriawati \& Margawati E.T. (2017): Genetic polymorphism of kappacasein gene in Friesian Holstein: a basic selection of dairy cattle superiority. Journal of the Indonesian Tropical Animal Agriculture. pISSN 2087-8273 eISSN 24606278. 42(4):213-219. 